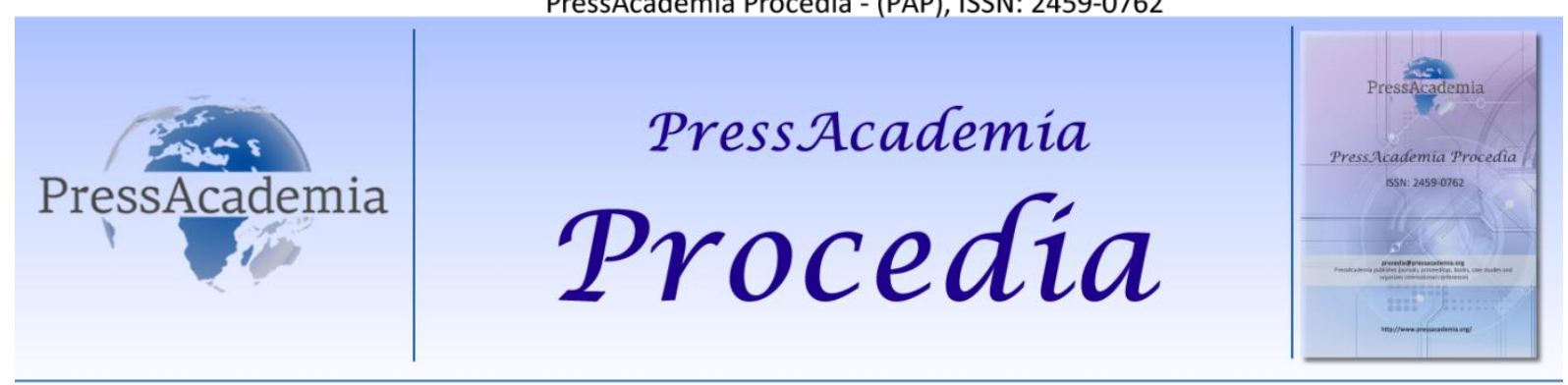

Global Business Research Congress (GBRC), May 24-25, 2017, Istanbul, Turkey.

\title{
NEW REGULATIONS RELATED TO UNPAID LEAVE AND PART-TIME WORK AFTER BIRTH
}

\author{
DOI: 10.17261/Pressacademia.2017.425
}

PAP-GBRC-V.3-2017(40)-p.392-401

Volkan Gunes

Istanbul Technical University., Istanbul, Turkey. gunesv@itu.edu.tr

\begin{abstract}
On 29.01.2016, a couple of amendments were introduced to the 4857 Labor Law with the Law No. 6663. These amendments are related to the Article 13 and Article 74 of the Labor Law, which respectively regulate the part time labor agreement and working in maternity period and breast feeding permission. Following these changes, "Regulation on Part-time Work after Maternity Leave and Unpaid Leave" entered into force through publication in the Official Gazette dated 08.11.2016. New amendments in question are broadly about right to use unpaid leave for one-half of working hours and right to work part-time. Thus, regarding the maternity in addition to the right for maternity leave and right for unpaid leave up to six months, right for unpaid leave for one-half of their working hours for a period of sixty days for the first birth, one hundred and twenty days for the second birth, and one hundred and eighty days for any subsequent births and right for part-time employment until the period in which the child starts compulsory elementary education were ensured. It is necessary to investigate all the aspects of these changes legally, which are also highly important in terms of practice.
\end{abstract}

Keywords: right to work part-time, right to unpaid leave for half of the working hours, part-time payment, maternity leave, parental leave. JEL Codes: J83, K31

\section{DOĞUM SONRASI ÜCRETSIZ IZNE VE KISMI SÜRELi ÇALIŞMAYA ILIŞKIN YENI DÜZENLEMELER}

\section{ÖZET}

29.01.2016 tarihinde 6663 sayılı kanun ile 4857 sayılı İş Kanunu'nun kısmi süreli iş sözleșmesini düzenleyen 13. maddesi ile analık halinde çalışma ve süt iznini düzenleyen 74. maddesinde değişiklikler yapılmışır. Bu değişikliklerin ardından "Analık İzni ve Ücretsiz İzin Sonrası Yapılacak Kısmi Süreli Çalışmalar Hakkında Yönetmelik" de 08.11.2016 tarihli Resmi Gazetede yayımlanarak yürürlüğe girmiştir. Söz konusu yeni düzenlemeler genel olarak haftalık çalışma süresinin yarısı kadar ücretsiz izin hakkı ve kısmi süreli çalışma hakkına ilişkindir. Böylece mevzuatımıza, kadın işçiye analık durumu ile alakalı olarak daha önceden tanınmış olan analık izni ile devamında altı aya kadar ücretsiz izin hakkına ek olarak iki hak daha eklenmiş olup bunlar benzer yöndeki uluslararası düzenlemelere yaklaşılması bağlamında önemlidir. Yeni düzenlemede birinci doğumda altmış gün, ikinci doğumda yüz yirmi gün, sonraki doğumlarda ise yüz seksen gün süreyle haftalık çalışma süresinin yarısı kadar ücretsiz izin hakkı ve çocuğun ilköğretim çağının başladığı döneme kadarki kısmi süreli çalışma hakkına yer verilmiştir. Çalışma hayatı açısından da büyük öneme sahip bu değişikliklerin hukuki açıdan tüm yönleriyle incelenmesi gerekmektedir.

Anahtar Kelimeler: kısmi süreli çalışma hakkı, çalışma süresinin yarısı kadar ücretsiz izin hakkı, yarım çalışma ödeneği, analık izni, ebeveyn izni.

JEL Kodları: J83, K31

\section{GiRiş}

İ̧̧ sözleşmesinin en önemli özelliklerinden biri sürekli borç ilişkisi yaratmasıdır. Bunun sonucu, alacaklının edime olan menfaatinin gerçekleşmesinin zaman içinde tekrarlanarak devam etmesidir. Yani iş görme borcunun işçi tarafından sürekli olarak ifa edilmesi suretiyle işverenin edime olan menfaati devamlı olarak gerçekleştirilir (Süzek, 2016: 257). Ne var ki bu sürekli borç ilişkisi devamı sırasında iş̧̧inin iş görme borcunu yerine getirmesini olanaksız kılan bazı durumlarla karşılaşılması doğaldır. Zira işçinin bu sözleşmenin tarafı olmasının yanı sıra ortaya koyduğu emek dolayısıyla aynı zamanda sözleşmenin konusunu da teşkil ettiği ortadadır. Böyle olunca özellikle insanın doğasından kaynaklanan bazı haller işçinin iş görme borcunun yerine getirememesini haklı kılabilir. Bunlardan bir tanesi de analık halidir. Gebelikten başlayıp, doğum ve doğum sonrasını da kapsar biçimde işçinin iş görme borcunun ifasının mümkün olmadığı ya da bunun beklenemeyeceği hallerle karşılaşılabileceği gibi Anayasa m. 50 gereği başkaca özel koruyucu hükümlerin sevki de gereklidir.

Türk iş hukuku mevzuatında analık hali ile ilgili olmak üzere özellikle kadın işçiyi koruyucu bazı hükümler mevcuttur. Söz konusu düzenlemelerin etki alanı oldukça geniştir. İ̧ sözleşmesinin kurulmasından sona ermesine ve özellikle de çalışma 
koşullarına ilişkin olmak üzere gebelik ve doğum sonrasını da kapsar biçimde analık hali bağlamında kadın işçi özel olarak korunmaya çalışılmıştır. Ne var ki söz konusu düzenlemeler, bazı yönleriyle uluslararası düzenlemelere kıyasla eksik kalmıştır. Çeşitli dönemlerde bu eksikliklerin giderilmesine yönelik gelişmeler yaşanmıştır. Son olarak 6663 sayılı Gelir Vergisi Kanunu ile Bazı Kanunlarda Değişiklik Yapılmasına Dair Kanun (RG., 10.02.2016, S. 29620) ile doğum sonrasına ilişkin olmak üzere 4857 sayılı iş Kanunu (RG., 10.06.2003, S. 25134) ve 4447 sayılı İşsizlik Sigortası Kanunu'nda (RG., 08.09.1999, S. 23810) bir takım değişiklikler yapılmıştır. Bu kapsamda Iş K.'nun kısmi süreli ve tam süreli iş sözleşmesini düzenleyen 13. maddesi ile analık halinde çalışma ve süt iznini düzenleyen 74. maddesi değiştirilmiş, İşsizlik Sigortası K.'na "doğum ve evlat edinme sonrası yarım çalışma ödeneği" kenar başlıklı ek madde 5 vazedilmiştir. Bunlardan başka Analık İni veya Ücretsiz İzin Sonrası Yapılacak Kısmi Süreli Çalışmalar Hakkında Yönetmelik (RG., 08.10.2016, S. 29882) de yürürlüğe girmiştir. Bu çalışma da esas olarak söz konusu değişikliklere ilişkin olmak üzere doğum sonrası haftalık çalışma süresinin yarısı kadar ücretsiz izin ile kısmi süreli çalışmaya özgülenmiştir. Dolayısıyla analık hali bağlamında mevzuatımızda önceden düzenlenmiş diğer bazı koruyucu hükümler ile özellikle analık izni ve altı aya kadar ücretsiz izne ilişkin düzenlemeler konunun sınırlanması bağlamında kapsam dışı bırakılmıştır (Son değişikler bağlamında olmak üzere doğum sonrası döneme ilişkin analık izninin doğumda ya da doğum sonrasında annenin ölümü halinde babaya kullandırılması ve analık izni ile altı aya kadar ücretsiz izin bağlamında üç yaşını doldurmamış çocuğu evlat edinen eşlerden birine ya da evlat edinene de bunlardan yararlanma hakkının hüküm altına alındığını belirtmek isteriz). Ancak İ̧̧ K. m. 74/2 doğrudan çalışma konumuzu oluşturduğundan aynı maddeye eklenen 7. fıkradan burada kısaca bahsetmek gerekir. Buna göre 74. madde hükümleri iş sözleşmesi ile çalışan ve İş K.'nun kapsamında olan veya olmayan -ki bundan Borçlar K., Basın İş K., Deniz İş K. kapsamındakiler anlaşılmalıdır- her türlü işçi için uygulanacaktır.

\section{HAFTALIK ÇALIŞMA SÜRESININ YARISI KADAR ÜCRETSIZ IZIN}

\subsection{Genel Olarak}

6663 sayılı Kanun ile İş K.'nun analık halinde çalışma ve süt iznini düzenleyen 74. maddesinde bazı değişiklikler yapılmıştır. Buna göre ilgili maddenin ikinci fıkrası olarak şu düzenleme vazedilmiştir:

"Birinci fıkra uyarınca kullanılan doğum sonrası analık hâli izninin bitiminden itibaren çocuğunun bakımı ve yetiştirilmesi amacıyla ve çocuğun hayatta olması kaydıyla kadın iş̧̧i ile üç yaşını doldurmamış çocuğu evlat edinen kadın veya erkek iş̧̧ilere istekleri hâlinde birinci doğumda altmış gün, ikinci doğumda yüz yirmi gün, sonraki doğumlarda ise yüz seksen gün süreyle haftalık çalışma süresinin yarısı kadar ücretsiz izin verilir. Çoğul doğum hâlinde bu sürelere otuzar gün eklenir. Çocuğun engelli doğması hâlinde bu süre üç yüz altmış gün olarak uygulanır. Bu fıkra hükümlerinden yararlanılan süre içerisinde süt iznine ilişkin hükümler uygulanmaz."

Bununla ilgili olmak üzere bir diğer değişiklik de İşsizlik Sigortası K.'nda yapılmış olup kanuna "doğum ve evlat edinme sonrası yarım çalışma ödeneği" kenar başlıklı ek madde 5 eklenmiştir:

"Iş̧̧iye, 4857 sayılı Kanunun 74 üncü maddesinin ikinci fıkrası uyarınca haftalık çalışma süresinin yarısı kadar verilen ücretsiz izin süresince doğum ve evlat edinme sonrası yarım çalışma ödeneği ödenir. Ödenek süresi, 4857 sayılı Kanunun 63 üncü maddesinde belirtilen haftalık çalışma süresinin yarısı kadardır. Yarım çalışma ödeneği, çalışılan aya ait aylık prim ve hizmet belgesinin ilişkin olduğu aydan sonraki ikinci ay içinde Fondan aylık olarak ödenir. Doğum ve evlat edinme sonrası yarım çalışma ödeneğinin günlük miktarı, günlük asgari ücretin brüt tutarı kadardır. Bu madde hükümlerinden yararlanılabilmesi için iş̧inin adına doğum veya evlat edinme tarihinden önceki son üç yılda en az 600 gün işsizlik sigortası primi bildirilmiş olması, 4857 sayılı Kanunun 63 üncü maddesinde belirtilen haftalık çalışma süresinin yarısı kadar fiilen çalışılması ve doğum ve evlat edinme sonrası analık hâli izninin bittiği tarihten itibaren 30 gün içinde Kuruma doğum ve evlat edinme sonrası yarım çalışma belgesi ile başvuruda bulunulması gerekir. Mücbir sebepler dışında, başvuruda gecikilen süre doğum ve evlat edinme sonrası yarım çalışma ödeneği almaya hak kazanılan toplam süreden düşülerek ödeme yapılır. Bu ödemeler damga vergisi hariç herhangi bir vergi ve kesintiye tabi tutulmaz. Geçici iş göremezlik ödeneği almaya hak kazananlara, bu durumlarının devamı süresince doğum ve evlat edinme sonrası yarım çalışma ödeneği ödenmez. İsverenin hatalı bilgi ve belge vermesi nedeniyle yapılan yersiz ödemeler kanuni faiziyle birlikte işverenden tahsil edilir. Bu madde hükümleri 506 sayılı Kanunun geçici 20 nci maddesi kapsamındaki sandıkların statülerine tabi personel için de uygulanır.

Birinci fıkra kapsamındaki sigortalılar için, 5510 sayılı Kanunun 82 nci maddesinde belirtilen prime esas kazanç alt sınırı üzerinden aynı Kanunun 81 inci maddesinin birinci fıkrasının (a) ve (f) bentleri uyarınca toplam \%32,5 oranında sigorta primleri iş̧̧i ve işveren payları doğum ve evlat edinme sonrası yarım çalışma ödeneği ödenen gün sayısı kadar Fondan Sosyal Güvenlik Kurumuna ödenir. 5510 sayılı Kanun kapsamında, Kurum prim ödeme yükümlüsü olmakla birlikte işyeri ve işveren sayılmaz ve bu kişiler için işe giriş ve çıkış bildirimi yapılmaz.

Bu maddenin uygulanmasına ilişkin usul ve esaslar Maliye Bakanlığı, Sosyal Güvenlik Kurumu, Kurum ve Hazine Müsteşarlığı tarafından müştereken belirlenir."

\subsection{Haftalık Çalışma Süresinin Yarısı Kadar Ücretsiz İzne Hak Kazanmanın Şartları ve Hükümleri}

Haftalık çalışma süresinin yarısı kadar ücretsiz izin hakkından yararlanabilecek olanlar, doğum yapan kadın işçi ile üç yaşını doldurmamış çocuğu evlat edinen kadın veya erkek işçiler olarak belirtilmiştir. Dolayısıyla söz konusu haktan, evlat edinme 
hali dışında, erkek işçi yararlanamayacaktır. Hangi gerekçeyle olursa olsun söz konusu hakkın erkek işçiye tanınmaması düzenlemeyi eleştiriye açık hale getirmektedir.

Doğum yapan kadın iş̧̧inin bu haktan yararlanabilmesi için çocuğun hayatta olması da şarttır. Evlat edinenin bu haktan yararlanabilmesi için ise çocuğun evlat edinme sırasında üç yaşından küçük olması yeterli kabul edilmelidir (Çelik, Caniklioğlu ve Canbolat, 2016: 599). Söz konusu haktan yararlanmak isteyen işçinin talebinin işverence reddi mümkün değildir. Bu noktada kanundan doğan bir değiştirici yenilik doğuran haktan söz edilir (Ekonomi, 2017: 24). Haftalık çalışma süresinin yarısı kadar ücretsiz izin hakkından faydalanmak isteyen iş̧̧inin, aşağıda açıklanacağı üzere kısmi süreli çalışma hakkında olduğu gibi işverene belirli süre önce bunu bildirme yükümlülüğünden söz edilmiş değildir. Bu noktada işverenin gerekli önlemleri alabilmesi için gereken makul bir süre önce yapılan bildirim yeterli kabul edilmelidir (Kısmi süreli çalışma hakkına ilişkin İş K. m. 13/5'te öngörülen sürenin haftalık çalışma süresinin yarısı kadar ücretsiz izin hakkı bakımından da kıyasen uygulanabileceği görüşü için bkz. Ekonomi, 2017: 32).

Haftalık çalışma süresinin yarısı kadar ücretsiz izin hakkından yararlanmak isteyen işçinin bu haktan yararlanacağı süre kanun koyucu tarafından sınırlandırılmıştır. Buna göre, birinci doğumda altmış gün, ikinci doğumda yüz yirmi gün, sonraki doğumlarda ise yüz seksen gün süreyle bu haktan yararlanmak mümkündür. Çoğul doğum hâlinde bu sürelere otuzar gün eklenirken çocuğun engelli doğması hâlinde ise bu süre üç yüz altmış gün olarak uygulanır. Çocuğun engelli doğması bakımından kaçıncı çocuk olduğuna göre değişen sürelerin olmadığı, bu halde sürenin doğrudan üç yüz altmış gün olarak uygulanacağına dikkat etmek gerekir. İlgili fıkranın ikinci ve üçüncü cümlelerinde düzenlenen çoğul doğum ile çocuğun engelli doğmasına ilişkin düzenlemelerin ilk cümle ile bağlantısının devam ettiği ve dolayısıyla birden çok çocuğun aynı anda evlat edinilmesi ile engelli çocuğun evlat edinilmesi hallerinde de uygulama alanı bulması gerektiği kanaatindeyiz. Ayrıca çoğul gebelikte engelli çocuğun varlığı halinde esas alınması gereken süre de üç yüz altmış gün olmalıdır (Çelik, Caniklioğlu ve Canbolat, 2016: 600-601). Bu noktada bu sürelerin arttırılıp arttırılamayacağı hususuna da değinmek gerekir. Haftalık çalışma süresinin yarısı kadar ücretsiz izin hakkına ilişkin düzenleme iş K.'nun 74. maddesinin 2. fıkrasına yerleştirilmiştir. Maddenin bundan sonra gelen ve eski halinde de aynen bulunan üçüncü fıkrasında ise "yukarıda öngörülen süreler işçinin sağlık durumuna ve işin özelliğine göre doğumdan önce ve sonra gerekirse artırılabilir. Bu süreler hekim raporu ile belirtilir." hükmü yer almaktadır. Kanun koyucunun değişikliği ikinci fıkrada düzenlemesi ile üçüncü fıkradaki "yukarıda öngörülen süreler" ibaresinden gerek birinci gerekse de ikinci fıkrada belirtilen süreleri kapsadığı sonucuna ulaşmak gerekir. Dolayısıyla analık iznine ilişkin doğumdan önceki ve sonraki sürelerden başka altmış, yüz yirmi, yüz seksen gün ile şartları oluştuğu takdirde bunlara eklenecek otuzar günlük süreler ve üç yüz altmış günlük sürenin hekim raporu ile arttırılması mümkündür.

Haftalık çalışma süresinin yarısı kadar ücretsiz izin hakkının kullanılması ile ilgili en önemli tartışmalardan biri bu hakkın kullanılabileceği an bakımından yaşanacaktır. Esasında iş K. m. 74/2'de "birinci fıkra uyarınca kullanılan doğum sonrası analık hâli izninin bitiminden itibaren" denilerek bu hakkın kullanılabileceği an açıkça düzenlenmiş bulunmaktadır. Ne var ki ilgili düzenleme, m. 74/6 ile birlikte değerlendirildiğinde bir takım uygulama sorunlarının doğması mümkün görünmektedir. İş K. m. 74/6 ile kadın işçiye isteği halinde verilecek altı aylık ücretsiz izin düzenlenmektedir: "isteği halinde kadın işçiye, on altı haftalık sürenin tamamlanmasından veya çoğul gebelik halinde on sekiz haftalık süreden sonra altı aya kadar ücretsiz izin verilir". Dolayısıyla gerek haftalık çalışma süresinin yarısı kadar ücretsiz izin hakkının gerekse de altı aya kadar ücretsiz izin hakkının kullanılabilmesi analık izninin bitimi ile mümkündür. Her iki haktan da yararlanmanın mümkün olup olmadığı yani bunların seçimlik nitelik taşıyıp taşımadıkları ile her iki haktan da yararlanmanın mümkün kabul edildiği takdirde bunlardan hangisinin önce kullanılacağına ilişkin bir açıklık madde metninde yoktur. Yine Analık İzni veya Ücretsiz İzin Sonrası Yapılacak Kısmi Süreli Çalışmalar Hakkında Yönetmelik'in haftalık çalışma süresinin yarısı kadar ücretsiz izin hakkını düzenleyen 6. maddesi ile altı aya kadar ücretsiz izin hakkını düzenleyen 7. maddesinde de kanundakine benzer şekilde analık izninin bitimine atıf yapılmıştır. Bu iki hakkın seçimlik olarak düzenlenip düzenlenmediği meselesi bakımından öğretide bizim de katıldığımız görüş, işçinin isterse her iki izni de kullanabileceğini, bu iki izin arasında bir bağlantı olmadığını belirtmektedir (Köseoğlu, 2017: 109, dn. 43). Diğer bir görüşe göre ise analık izninin bitiminden sonra haftalık çalışma süresinin yarısı kadar ücretsiz izin hakkı ile altı aya kadar ücretsiz izin hakkından sadece birinin kullandırılması amaçlanmakta ve dolayısıyla bunların seçimlik nitelik taşıdığı üzerinde durulmaktadır (Ekonomi, 2017: 29-30). Bundan başka bir izin sıralamasının mevcut olup olmadığı üzerinde de durmak gerekir. Örneğin işçi analık izninin bitiminden itibaren altı aya kadar ücretsiz izin hakkını kullandığı durumda bu iznin bitiminden itibaren haftalık çalışma süresinin yarısı kadar ücretsiz izin hakkını kullanabilecek midir? Aynı soruyu sıralamayı ters çevirerek de sormak mümkündür. Bir görüşe göre işçi haftalık çalışma süresinin yarısı kadar ücretsiz izin hakkını kullanırsa altı aya kadar ücretsiz izin hakkını ancak bundan sonra kullanabilir (Ulusoy, 2017: 753). Her iki izin hakkının kullanılacağı an bakımından analık izninin bitimi esas alınarak düzenleme yapılmış olması bunların kullanım hakkının işçiye bırakılmasından kaynaklanmaktadır. Yani işçi analık izninin bitiminden sonra bunlardan birini seçerek kullanabilecek, diğerini ise hiç kullanmayabilecektir. Ne var ki haftalık çalışma süresinin yarısı kadar ücretsiz izin hakkı kullanılmak isteniyorsa bunun altı aya kadar ücretsiz izin hakkından evvel kullanılması gerektiği aksi halde kullanılamayacağını kabul etmek mümkün olmamalıdır. Aksinin kabulünün halin icabı ile uyuştuğunu söylemek de zordur. Zira çocuğun anneye gereksinimi ilk zamanlarda daha fazladır. Bu gereksinimin nispeten azaldığı dönemde haftalık çalışma süresinin yarısı kadar ücretsiz izin hakkının kullanılmak istenmesi doğaldır. Yine İşsizlik Sigortası K.'nun ek 5. maddesinde doğum ve evlat edinme sonrası analık hâli izninin bittiği tarihten itibaren 30 gün içinde Kuruma doğum ve evlat edinme sonrası yarım çalışma belgesi ile başvuruda bulunulması gerektiği ve mücbir sebepler dışında, başvuruda gecikilen süre doğum ve evlat edinme sonrası yarım çalışma ödeneği almaya hak kazanılan toplam 
süreden düşülerek ödeme yapılacağı hüküm altına alınmıştır. Burada da İş K.'nda olduğu gibi analık izninin bittiği tarihten bahsediliyor olması, haftalık çalışma süresinin yarısı kadar ücretsiz izin hakkının ancak altı aya kadar ücretsiz izin hakkından evvel kullanılabileceği aksi halde ise kullanılamayacağının kabulü bağlamında esas teşkil edemeyeceği kanaatindeyiz. Analık izninin bitiminden sonra altı aya kadar ücretsiz izin hakkından yararlanıldıysa yarım çalışma ödeneği için öngörülen 30 günlük başvuru süresinin ücretsiz iznin bitiminden itibaren hesaplanması gerekir.

Haftalık çalışma süresinin yarısı kadar ücretsiz izin hakkı ile ilgili olarak değinilmesi gereken hususlardan bir diğeri de "haftalık çalışma süresinin yarısı"ndan ne anlaşııması gerektiğidir. İ̧̧ K. m. 63'te genel bakımdan çalışma süresi haftada en çok 45 saat olarak belirlenmiştir. Ne var ki tarafların 45 saatin altında haftalık çalışma süresi kararlaştırmaları mümkündür. Dolayısıyla haftalık çalışma süresinin yarısı belirlenirken ilgili işçinin fiili haftalık çalışma süresi dikkate alınacaktır. Örneğin haftalık çalışma süresi 40 saat olan bir işçi haftalık çalışma süresinin yarısı kadar ücretsiz izin hakkından yararlanacağı süre de 20 saat olacaktır. Bu noktada söz konusu haktan yararlanılması bakımından iş sözleşmesinin türünün bir önemi yoktur. Dolayısıyla kısmi süreli iş sözleşmesi ile çalışan işçiler de bu haktan yararlanabilir (Bir görüşe göre haftalık çalışma süresi, örneğin 18,6 ya da 4 saat gibi çok daha az olan işçiler bakımından bu hakkın kullanılması amaca uygun olmayıp 63. maddeye yapılan atıf da bunu desteklemektedir. Zira 63. madde tam süreli iş sözleşmesini esas almakta olup haftalık çalışma süresinin yarısı kadar ücretsiz izin hakkından da ancak tam süreli iş sözleşmesi ile çalışan işçiler faydalanacaktır. Ekonomi, 2017: 2728). Bundan başka İ̧̧ K. m. 63'te ayrıca haftalık çalışma süresinin işyerlerinde haftanın çalışılan günlerine eşit ölçüde bölünerek uygulanacağı da hüküm altına alınmışsa da bu kuralın da taraflarca aksinin kararlaştırılması mümkündür. Günlük çalışma süresinin bu şekilde atipik hale getirildiği iş sözleşmeleri bakımından işçinin hangi sürelerde çalışma süresinin yarısı kadar ücretsiz izin hakkından yararlanacağı sorunu ile karşılaşılması söz konusudur. Bu noktada "haftalık çalışma süresi”nin, "günlük çalışma süresi" olarak anlaşılması gerekir (Köseoğlu, 2017: 107). Dolayısıyla haftalık çalışma süresinin yarısı kadar ücretsiz izin hakkının kullanılmasında, taraflarca haftanın çalışılan günlerine eşit ölçüde bölünerek belirlenmemiş günlük çalışma sürelerinin yarısı kadar çalışılacaktır. Yine haftalık çalışma süresinin yarısı kadar ücretsiz izin hakkı kullanılırken çalışılmayacak sürelerin birleştirilmesi suretiyle toplu olarak kullanılıp kullanılamayacağı hususunda öğretide farklı görüşlerin olduğu tespit edilmektedir. Bir görüşe göre, işçi izninin, örneğin yüz yirmi günlük sürenin ilk altmış gününü izinli, kalan altmış gününü ise çalışarak geçiremeyecek, buna karşııık haftalık çalışmanın üç gününü çalışmamak veya her gün sadece yarım gün çalışma biçiminde kullanabilecektir (Çelik, Caniklioğlu ve Canbolat, 2016: 601). Diğer bir görüşe göre ise işçinin bu izni toplu olarak kullanması hiçbir şekilde mümkün olmayıp bu izinden yararlanan işçinin süt izninden yararlanamayacağına ilişkin gerek işs K. m. 74/2'deki gerekse de Yönetmelik m. 6/4 hükümleri de bunu destekler niteliktedir (Köseoğlu, 2017: 107, dn. 39). Söz konusu sürelerin birleştirilmesi suretiyle toplu olarak kullanılıp kullanılamayacağına ilişkin benzer nitelikli bir tartışma da süt izni bakımından yapılmaktadır. Bu bağlamda süt izninin toplu olarak kullanılabileceğine ya da kullanılamayacağına ilişkin olarak niteliği gereği bunun toplu olarak kullanılamaması gerekir. Buna rağmen özellikle uygulamada süt izninin toplu olarak kullandırılığı görülmektedir. Zira kadın iş̧̧inin evi ile işyeri arasındaki mesafe ve özellikle büyük kentlerdeki ulaşım problemlerinden ötürü kanunun süt iznini düzenlerken güttüğü amaç, bu iznin her gün kullanılmasından ziyade birleştirilerek toplu olarak kullanılmasıyla gerçekleşmektedir. Ne var ki haftalık çalışma süresinin yarısı kadar ücretsiz izin hakkı bakımından izin sürelerinin birleştirilmesi suretiyle toplu olarak kullanılması bakımından aynı sonuca ulaşmak mümkün görünmemektedir. Zira buradaki süre çoğu zaman süt iznindeki günlük bir buçuk saatlik izin süresi ile kıyaslanamayacak uzunluktadır. Dolayısıyla haftalık çalışma süresinin yarısı kadar ücretsiz izin hakkında bu sürelerin birleştirilmesi suretiyle toplu olarak kullanılması kanaatimizce mümkün olmamalıdır.

\subsection{Yarım Çalışma Ödeneği}

\subsubsection{Yarım Çalışma Ödeneğinden Yararlanma Şartları}

Haftalık çalışma süresinin yarısı kadar ücretsiz izin hakkını, ücretsiz izin hakkından ya da kısmi süreli çalışmadan ayıran en önemli özellik ücretsiz izin süresince yarım çalışma ödeneğinden yararlanılacak olmasıdır. İşçinin ücret alacağından ancak çalıştığı süreye orantılı olarak yararlanacağı göz önüne alındığında ödeneğin işçi için ne kadar önemli olduğu daha iyi anlaşılacaktır. Yarım çalışma ödeneğinden yararlanmanın ilk şartı belirli bir süre işsizlik sigortası primi ödenmiş olmasıdır. Bu şarta ilişkin olarak İşsizlik Sigortası K. ek m. 5'te işçinin adına doğum veya evlat edinme tarihinden önceki son üç yılda en az 600 gün işsizlik sigortası primi bildirilmiş olması gerektiği düzenlenmiştir. Belirli bir süre işsizlik sigortası primi ödenmesine ilişkin bu şart, işsizlik ödeneğinden yararlanmak için gerekli olan ve benzer nitelikte taşıyan şarta nazaran yumuşatılmıştır. İşsizlik Sigortası K. m. 51/1'de işsizlik ödeneğinden yararlanabilmek için hizmet akdinin sona ermesinden önceki son üç yıl içinde en az 600 gün sigortalı olarak çalışıp işsizlik sigortası primi ödemiş olmak ve işten ayrılmadan önceki son 120 gün içinde de prim ödeyerek sürekli çalışmış olmak da gerekmektedir. İşten ayrılmadan önceki son 120 gün içinde prim ödeyerek sürekli çalışmış olma şartının yarım çalışma ödeneği bakımından aranmaması, yarım çalışma ödeneğinden yararlanacak dönemin niteliği gereğidir. Aksi halde bu ödeneğe hak kazanma başlangıçta imkânsız hale gelirdi. Zira yarım çalışma ödeneğinden yararlanacak işçinin analık izninden dolayı kural olarak doğumdan önce sekiz ve doğumdan sonra sekiz haftalık sürede prim ödeyerek sürekli çalışmasından bahsetmek mümkün değildir. 4447 Sayılı Işsizlik Sigortası Kanununun Uygulanmasına İlişkin Tebliğ, Tebliğ No:3 (RG., 30.01.2002, S. 24656) m. 2/2'de prim yatırılmayan bazı sürelerin kesinti sayılmayacağı düzenlenmiş olsa da bunlar arasında analık hali sayılmamaktadır (Söz konusu hükme göre, hizmet akdinin sona erdiği tarihten önceki son 120 gün içinde, hizmet akdi devam etmekle birlikte, hastalık, ücretsiz izin, disiplin cezası, gözaltına alınma, hükümlülükle sonuçlanmayan tutukluluk hali, kısmi istihdam ile grev, lokavt, genel hayatı etkileyen olaylar, 
ekonomik kriz, doğal afetler nedeniyle işyerinde faaliyetin durdurulması veya işe ara verilmesi halinde, prim yatırılmayan süreler için Sosyal Sigortalar Kurumu (SSK) kayıtları esas alınır ve 120 günün hesabında prim yatırılmayan bu süreler kesinti sayılmaz.). Bekleme süresi bakımından yarım çalışma ödeneğinden yararlanacak olan işçi bakımından, işsizlik ödeneğinden yararlanmada olduğu gibi son üç yılda en az 600 gün işsizlik sigortası primi bildirilmiş olması şartının aranması da kanaatimizce yerinde değildir. Zira aynı kanunda düzenlense de esas olarak bu iki kurum birbirinden farklı niteliklere sahiptir. Bu noktada işsizlik ödeneğindense analık izni süresince analık sigortası kapsamında hak kazanılacak geçici iş göremezlik ödeneğinin bekleme süresine ilişkin koşullar göz önünde bulundurularak doğum veya evlat edinme tarihinden önceki bir yıl içinde en az 90 gün işsizlik sigortası primi ödenmesinin benimsenmesi daha isabetli bir çözüm olabilirdi.

Yarım çalışma ödeneğinden yararlanılabilmesi için getirilen ikinci şart, i̇s K. m. 63'te belirtilen haftalık çalışma süresinin yarısı kadar fiilen çalışımasıdır. Her ne kadar fiilen çalışmadan bahsediliyorsa da İş $\mathrm{K} . \mathrm{m} 66^{\prime}$ da düzenlenen çalışma süresinden sayılan hallerin de yarım çalışma ödeneğine hak kazanılması bakımından dikkate alınması gerekir (Bunlardan m. 63/1-e'de düzenlenen çocuk emziren kadın işçilerin çocuklarına süt vermeleri için belirtilecek sürelerin ise İş K. m. 74/2'deki haftalık çalışma süresinin yarısı kadar ücretsiz izin süresi içerisinde süt iznine ilişkin hükümlerin uygulanmayacağına ilişkin açık düzenlemesi gereği uygulama alanı bulamayacağını belirtmek isteriz).

İşsizlik Sigortası K. ek m. 5'te öngörülen üçüncü şart olarak, doğum ve evlat edinme sonrası analık hâli izninin bittiği tarihten itibaren 30 gün içinde Kuruma doğum ve evlat edinme sonrası yarım çalışma belgesi ile başvuruda bulunulması gerektiği düzenlenmiştir. Mücbir sebepler dışında, başvuruda gecikilen sürenin yaratacağı etki ise gecikilen sürenin doğum ve evlat edinme sonrası yarım çalışma ödeneği almaya hak kazanılan toplam süreden düşülerek ödeme yapılmasıdır. Dolayısıyla 30 günlük sürenin hak düşürücü niteliğinden bahsetmek mümkün değildir. Yukarıda açıklandığı üzere maddede analık hâli izninin bittiği tarihten bahsediliyor olsa da analık hâli izninin bittiği tarihten itibaren altı aya kadar ücretsiz izin hakkından yararlanılması mümkün olup bu halde 30 günlük sürenin altı aya kadar ücretsiz iznin bitiminden itibaren hesaplanması gerekir. Bunun dışında yarım çalışma ödeneğinden yararlanılabilmesi için Türkiye iş̧ Kurumu'na doğum ve evlat edinme sonrası yarım çalışma belgesi ile başvuruda bulunulması gerektiği hüküm altına alınmış olup söz konusu belgenin işverence düzenlenmesinin reddi işçinin ödeneğe hak kazanması önünde bir engel olarak nitelendirilebilir. Kanaatimizce hakkın kullanılması noktasında bürokratik bir engel yaratılması yerine iş̧̧inin analık izninin bitiminden itibaren Kuruma doğum belgesini içeren bir dilekçe ve resmi kimlik belgesi ile bizzat yapacağı başvuru, yarım çalışma ödeneğinin verilmesi için aranan diğer şartların da varlığı halinde geçerli kabul edilmelidir (Belge ile başvurma şartı işsizlik ödeneği için de söz konusu olup sigortalının bu işten ayrılma belgesi ile Kuruma başvurması gerekmektedir. Ne var ki 4447 Sayılı İşsizlik Sigortası Kanununun Uygulanmasına ïlişkin Tebliğ Tebliğ No:3 m. 5/2'de işverenin işten ayrılma bildirgesi düzenlememesi halinde, hak kaybına yol açılmaması için sigortalı işsizin talep dilekçesi ve resmi kimlik belgesi ile yaptığı müracaatı kabul edileceği düzenlenmiştir. Yarım çalışma ödeneği bakımından da benzer yönde bir hüküm sevk edilinceye kadar uygulamada yukarıda belirttiğimiz şekilde yapılan müracaatların kabulü sağlanmalıdır).

Yarım çalışma ödeneğinden yararlanılabilmesi için gerekli olan son şart ise geçici iş göremezlik ödeneği almaya hak kazanmamış olmaktır. Aksi halde geçici iş göremezlik ödeneği almaya hak kazandıran halin devamı süresince yarım çalışma ödeneği ödenmez. Geçici iş göremezlik ödeneği genel olarak 5510 sayılı Sosyal Sigortalar ve Genel Sağlık Sigortası Kanunu'nun 18. maddesinde düzenlenmiştir. Buna göre sigortalının geçici iş göremezlik ödeneğine hak kazanması için öncelikle iş kazası, meslek hastalığı, hastalık ya da analık hallerinden birinin varlığı sonucu iş göremezliğe uğraması gerekir. Analık sigortası kapsamında geçici iş göremezlik ödeneği ile yarım çalışma ödeneğinin çakışmasından söz edilemez. Zira analık hali izninin bitiminden evvel yarım çalışma ödeneğine hak kazanılması mümkün değildir. Bunun dışında iş kazası, meslek hastalığı ya da hastalık halleri bakımından geçici iş göremezlik ödeneğine hak kazanılması hususunda SSGSSK'da belirtilen şartların da gerçekleşmiş olması gerekir (Söz konusu haller bakımından geçici iş göremezlik ödeneğine hak kazanılması için gerekli şartlar konusunda ayrıntılı bilgi için bkz. Sözer, 2015: 224 vd., 347 vd.). Yarım çalışma ödeneğinden yararlanan sigortalıya iş kazası geçirmesi, meslek hastalığına tutulması ya da hastalanması halinde kanunun aradığı diğer şartların da varlığı ile geçici iş göremezlik ödeneğine hak kazanması sonucu bu halin devamı süresince yarım çalışma ödeneği ödenmeyecektir. Son olarak geçici iş göremezlik ödeneği ile yarım çalışma ödeneğinin miktarları göz önünde bulundurulduğunda ortaya çıkması muhtemel bir soruna değinmek isteriz. Yukarıda bahsedilen kısa vadeli sigorta kollarının tamamı bakımından sigortalının hak kazandığı geçici iş göremezlik ödeneğinin miktarı yatarak tedavilerde günlük kazancın (günlük kazancın hesaplanması ile ilgili olarak bkz. SSGSSK m. 17) yarısı, ayakta tedavilerde ise üçte ikisidir. Yarım çalışma ödeneğinin günlük miktarı ise günlük asgari ücretin brüt tutarı kadardır. Bu noktada yarım çalışma ödeneği miktarının geçici iş göremezlik ödeneği miktarını aşması söz konusu olduğu durumlarda, geçici iş göremezlik ödeneğinden yararlanmak için hastalık sigortası bakımından Kuruma başvuruda bulunulması şartı, iş kazası ve meslek hastalığı sigortası bakımından ise bildirim yükümlülüğünün varlığı söz konusu başvuru ya da bildirimin yapılmasından kaçınılmak suretiyle somut olayda miktarı daha yüksek olan yarım çalışma ödeneğinden yararlanmaya devam edilmesi sağlanabilir. Talep ya da bildirim yükümlülüğünün yerine getirilmesi geçici iş göremezlik ödeneğine hak kazanılması bakımından kurucu unsur olarak kabul edildiğinde iki ödenek miktarı arasında oluşacak farkın yersiz ödeme olarak kabulü mümkün olmamalıdır. Bu konuda ortaya çıkabilecek tartışmaların önüne geçilmesi için iki halin çakışması durumunda ödenek miktarı yüksek olandan yararlanılacağı şeklinde bir düzenleme daha isabetli olurdu. Bundan başka İşsizlik Sigortası K. ek m. 5'te işverenin hatalı bilgi ve belge vermesi nedeniyle yapılan yersiz ödemelerin kanuni faiziyle birlikte işverenden tahsil edileceği belirtilmektedir. 


\subsubsection{Yarım Çalışma Ödeneğinin Hükümleri}

Yarım çalışma ödeneğinin süresi ve miktarı İşsizlik Sigortası K.'nun ek 5. maddesinde açıklanmıştır. Buna göre, yarım çalışma ödeneği doğum ve evlat edinme sonrası haftalık çalışma süresinin yarısı kadar verilen ücretsiz izin süresince ödenir. Bu süre daha önce açıklandığı üzere kaçıncı doğum olduğuna, çoğul doğum durumuna ya da doğan çocuğun engelli olup olmadığına göre 60 ile 360 gün arasında değişmektedir. Haftalık çalışma süresinin yarısı kadar ücretsiz izin hakkına ilişkin sürelerin sözleşme veya toplu iş sözleşmesi ile arttırılması halinde ödenekten faydalanma süresi de artmış olmaz (Ekonomi, 2017: 39). Bundan başka maddede ödenek süresinin, haftalık çalışma süresinin yarısı kadar olduğuna ilişkin bir hüküm de bulunmaktadır. Bu düzenleme ödeneğin süresinden ziyade ödeneğin hesaplanmasında haftanın tamamının değil yarısının esas alınacağını ifade etmektedir (Caniklioğlu, 2017: 148. Ödenek süresinin, haftalık çalışma süresinin yarısı kadar olduğuna iliş̧in düzenlemeyi, haftalık çalışma süresinin yarısı kadar ücretsiz izin hakkından ancak tam süreli iş sözleşmesi ile çalışan işçilerin yararlanabileceğine dayanak yapan görüş için bkz. Ekonomi, 2017: 27-28).

Haftalık çalışma süresinin yarısı kadar ücretsiz izin hakkını kullanan işçi, çalıştı̆̆ı süreye ilişkin ücretini işverenden alacak olup haftalık çalışma süresinin diğer yarısı bakımından da işKUR tarafından verilecek olan yarım çalışma ödeneğinden yararlanacaktır. Yarım çalışma ödeneğinin günlük miktarı, günlük asgari ücretin brüt tutarı kadar olup bu miktarın işçiye İşsizlik Sigortası Fonu'ndan aylık olarak ödeneceği hükme bağlanmıştır (2017 yılı için günlük asgari ücretin brüt tutarı 59.25 TL'dir). Yarım çalışma ödeneğinin İşsizlik Sigortası Fonu'ndan karşılanacak olması yerinde olmamıştır. Zira ülkemizdeki işsizlik oranları TÜiK'in Ocak 2017 verilerine göre \%13'e ulaşmıştır (http://www.tuik.gov.tr/HbGetirHTML.do?id=24626). Yine TÜik'in 2015 yılı için yapmış olduğu yayımlanan son doğum istatistiklerinde ülkemizde 2015 yılından canlı doğan bebek sayısı 1.325.783'tür (http://www.tuik.gov.tr/PreHaberBultenleri.do?id=21514). Bu rakamlarla birlikte ülkemizdeki kayıt dışı istihdamın ulaştığı boyutun finansman kaynaklarına olumsuz etkisi göz önüne alındığında yarım çalışma ödeneğinin ilerleyen dönemde Fonun erimesi bağlamında önemli bir etki yaratacak niteliktedir. Ayrıca Fon ile ilişkilendirilerek buradan karşılanan ücret alacakları ile ödenek türlerinin zaman içerisinde çoğaldığı da gözden uzak tutulmamalıdır. Mevcut durumda işsizlik ödeneği dışında ücret garanti fonu ve kısa çalışma ödeneğinin yanında yarım çalışma ödeneği de Fon ile ilişkilendirilmiştir.

Sosyal Güvenlik Kurumu'nun 01.09.2016 tarihli 2016/20 sayılı Genelgesi ile belirtildiği üzere, yarım çalışma ödeneği ödenen süreler sigortalılık süresi sayılacağından sigortalının prim gün sayısı bakımından bir kaybından söz edilmesi mümkün değildir. Haftalık çalışma süresinin yarısı kadar ücretsiz izin hakkını kullanan sigortalının sigorta primleri, SSGSSK m. 82'de belirtilen prime esas kazanç alt sınırı üzerinden SSGSSK m. 81/1-a ve m. 81/1-f uyarınca toplam \%32,5 oranında işçi ve işveren payları doğum ve evlat edinme sonrası yarım çalışma ödeneği ödenen gün sayısı kadar Fondan Sosyal Güvenlik Kurumuna ödenir. Dolayısıyla yarım çalışma ödeneği alan sigortalılar için işKUR, \%32,5 oranında uzun vade ve genel sağlık sigortası primini aylık prim ve hizmet belgesi ile SGK'ya bildirecektir. IŞKUR'un prim ödeme yükümlüsü olmakla birlikte işyeri ve işveren sayılmayacağı ve bu kişiler için işe giriş ve çıkış bildirimi yapılmayacağı kanunda açıkça düzenlenmiştir.

\section{KISMI SÜRELI ÇALIŞMA}

\subsection{Genel Olarak}

Kısmi süreli iş sözleşmesi iş K. m. 13'te düzenlenmiş olup kısmî süreli iş sözleşmesinin varlığı için işçinin normal haftalık çalışma süresinin, tam süreli iş sözleşmesiyle çalışan emsal iş̧̧iye göre önemli ölçüde daha az belirlenmesi gerekir (Kısmi süreli iş sözleşmesine ilişkin ayrıntılı açıklamalar için bkz. Süzek, 2016: 283 vd.; Çelik,Caniklioğlu ve Canbolat, $2016: 141$ vd.; Mollamahmutoğlu, Astarlı ve Baysal, 2014: 443 vd.). Çalışma konumuz özelinde kısmi süreli çalışma, i̇ş K. m. 13’e uygun şekilde Analık İzni veya Ücretsiz İzin Sonrası Yapılacak Kısmi Süreli Çalışmalar Hakkında Yönetmelik m. 4'te de tanımlanmıştır. Kısmi süreli iş sözleşmesinin varlığı için aranan "önemli ölçüde daha az" çalışma süresinden ne anlaşıması gerektiği kanunun gerekçesi ve iş̧ Kanununa iliş̧in Çalışma Süreleri Yönetmeliği (RG., 06.04.2004, S. 25425) m. 6'da açıklanmaktadır. Buna göre, işyerinde tam süreli iş sözleşmesiyle yapılan emsal çalışmanın üçte ikisi oranına kadar yapılan çalışma kısmi süreli çalışmadır. Dolayısıyla tam süreli iş sözleşmesi ile çalışan iş̧̧i için o işyerinde haftalık çalışma süresi 45 saat ise 30 saat ve altında yapılan emsal çalışma kısmi süreli çalışma olarak nitelendirilir. İş K. m. 13/2'de kısmi süreli iş sözleşmesi ile çalıştırılan işçinin, ayrımı haklı kılan bir neden olmadıkça, salt iş sözleşmesinin kısmi süreli olmasından dolayı tam süreli emsal iş̧̧iye göre farklı işleme tâbi tutulamayacağı düzenlenmiştir. Yine aynı madde kapsamında kısmi süreli çalışan işçinin ücret ve paraya ilişkin bölünebilir menfaatlerinin tam süreli emsal işçiye göre çalıştığı süreye orantılı olarak ödeneceği de düzenlenmektedir.

Kısmi süreli iş sözleşmesinin düzenlendiği İ̧̧ K. m. 13'e doğum sonrası dönemde kısmi süreli çalışmaya ilişkin olmak üzere 6663 sayılı Kanun ile 5. fıkra eklenmiş ve 6. fıkranın gereği olarak da Analık İzni veya Ücretsiz İzin Sonrası Yapılacak Kısmi Süreli Çalışmalar Hakkında Yönetmelik çıkartılmıştır. Yeni düzenlemeler esas olarak, bazı yönlerden eksikleri olsa da uluslararası düzenlemelerdeki çocuğun bakımı ve yetiştirilmesine ilişkin ebeveyn izinleri bağlamında değerlendirilmelidir. Bu noktada ebeveyn izinleri, iş hayatı ile aile hayatının bağdaştırılmasına hizmet eden, çalışanların çocuklarına bir süre bakabilmek için çalışma hayatından uzak kalmalarına imkân veren izinlerdir (Koç, 2016: 197). Şartları ve hükümleri aşağıda ayrıntılı olarak incelenecek olan doğum sonrası kısmi süreli çalışma hakkına ilişkin İş K. m. 13/5-6'da şöyledir:

"Bu kanunun 74 üncü maddesinde öngörülen izinlerin bitiminden sonra mecburi ilköğretim çağının başladığı tarihi takip eden aybaşına kadar bu maddeye göre ebeveynlerden biri kısmi süreli çalışma talebinde bulunabilir. Bu talep işveren 
tarafından karşılanır ve geçerli fesih nedeni sayılmaz. Bu fıkra kapsamında kısmi süreli çalışmaya başlayan işçi, aynı çocuk için bir daha bu haktan faydalanmamak üzere tam zamanlı çalışmaya dönebilir. Kısmi süreli çalışmaya geçen işçinin tam zamanlı çalışmaya başlaması durumunda yerine işe alınan işçinin iş sözleşmesi kendiliğinden sona erer. Bu haktan faydalanmak veya tam zamanlı çalışmaya geri dönmek isteyen iş̧i işverene bunu en az bir ay önce yazılı olarak bildirir. Ebeveynlerden birinin çalışmaması hâlinde, çalışan eş kısmi süreli çalışma talebinde bulunamaz. Üç yaşını doldurmamış bir çocuğu eşiyle birlikte veya münferiden evlat edinenler de çocuğun fiilen teslim edildiği tarihten itibaren bu haktan faydalanır.

Beşinci fıkra kapsamında hangi sektör veya işlerde kısmi çalışma yapılabileceği ile uygulamaya ilişkin usul ve esaslar Çalışma ve Sosyal Güvenlik Bakanlığınca çıkarılacak yönetmelikle belirlenir."

\subsection{Kısmi Süreli Çalışmaya Hak Kazanma Şartları}

Doğum sonrası kısmi süreli çalışma talebinde bulunabilecek olan kişi, ebeveynlerden biri olarak belirtilmiştir. Yine iş K. $\mathrm{m}$. $13 / 5^{\prime}$ te üç yaşını doldurmamış bir çocuğu eşiyle birlikte veya münferiden evlat edinenlerin de çocuğun fiilen teslim edildiği tarihten itibaren kısmi süreli çalışma talebinde bulunabileceği düzenlenmiştir. Kısmi süreli çalışma hakkının süjesi olarak sadece annenin belirlenmesi yerine ebeveynlerden herhangi birinin seçilmesi ne kadar yerinde olmuşsa ebeveynlerden biri ya da eşiyle birlikte evlat edinenlerden birinin kısmi süreli çalışma talebinde bulunulabilmesinin talepte bulunan dışındaki eşin çalışmaması koşuluna bağlanması o kadar yerinde değildir (Alman Hukukunda benzer yönde bir sınırlama bulunmadığı hakkında bkz. Caniklioğlu, 2017: 120). Zira bunun sonucunda erkeğe çalışma, kadına ise çocuğun bakımı görevini yükleyen toplumdaki geleneksel yapı varlığını sürdürecek ve hakkın süjesi büyük oranda kadın olacaktır. Diğer eşin çalışması şartı bakımından değinilmesi gereken başka bir husus da Yönetmelik ile buna bazı istisnalar getirilmiş olmasıdır. Yönetmeliğin 10. maddesinde ebeveynlerden birinin çalışma şartının aranmayacağı üç adet istisna sayılmıştır. Bunlardan ilki ebeveynlerden birinin sürekli bakım ve tedavisini gerektiren bir hastalığının olması ve bu hastalığın tam teşekküllü hastane ya da üniversite hastanesinden alınacak doktor raporuyla belgelendirilmesi, ikincisi velayetin mahkemece eşlerden birine verilmesi hâlinde çocuğun velayetine sahip ebeveynin talepte bulunması ve üçüncüsü üç yaşını doldurmamış bir çocuğun münferiden evlat edinilmesidir. Bu noktada diğer eşin çalışması şartına getirilen istisnaların sadece halin icabını yansıttığı söylenebilir. Bunun dışında eşin çalışması iş sözleşmesi ile sınırlı olarak anlaşılmamalı, eşin devlet memuru ya da kamu görevlisi veyahut bağımsız olarak çalışıyor olması da yeterli sayılmalıdır (Caniklioğlu, 2017: 120). Son olarak Yönetmelik m. 10/2'de kısmi süreli çalışma talebi bakımından diğer eşin çalışmasına ilişkin şartın, sadece başvuru sırasında aranacağı ve bu şartın kısmi süreli çalışma sırasında kaybedilmesi durumunda söz konusu hakkın devam edeceği düzenlenmiştir.

Kısmi süreli çalışma hakkından yararlanmak üzere talepte bulunulması için gerekli süre kanun koyucu tarafından sınırlandırılmıştır. Buna göre mecburi ilköğretim çağının başladığı tarihi takip eden aybaşına kadar kısmi süreli çalışma talebinde bulunulması gerekir (Mecburi ilköğretim çağının başladığı dönem Millî Eğitim Bakanlığı Okul Öncesi Eğitim ve Illköğretim Kurumları Yönetmeliği (RG., 26.07 2014, S. 29072) m. 11/6-a,b'de sırasıyla şu şekilde belirtilmiştir: "ilkokulların birinci sınıfına, kayıtların yapıldığı yılın eylül ayı sonu itibarıyla 66 ayını dolduran çocukların kaydı yapılır. Gelişim yönünden ilkokula hazır olduğu anlaşılan 60-66 ay arası çocuklardan, velisinin yazılı isteği bulunanlar da ilkokul birinci sınıfa kaydedilir. Okul müdürlükleri, yaş̧̧a kayıt hakkını elde eden çocuklardan 66, 67 ve 68 aylık olanları velisinin vereceği dilekçe; 69, 70 ve 71 aylık olanları ise ilkokula başlamaya hazır olmadıklarını belgeleyen sağlık raporu ile okul öncesi eğitime yönlendirebilir veya kayıtlarını bir yıl erteleyebilir."). Söz konusu düzenlemenin lafzı, normun amacına aykırı bulunarak öğretide eleştirilmiştir. Buna göre örneğin 2016 yılı için ilkokulların açıldığı tarih 19.09.2016 olup ilköğretim çağına gelen çocuğu olan işçi bu tarihi takip eden 01.10.2016 tarihine kadar kısmi süreli istihdama geçmek için talepte bulunabilecektir. Oysa bu tarih, normun amacı dikkate alındığında kısmi süreli istihdamın normal olarak sona ereceği/ermesi gereken süreyi de ifade etmektedir (Caniklioğlu, 2017: 127).

Kısmi süreli çalışma hakkının kullanılması için talepte bulunulabilmesi için İş K. m. 74'te öngörülen izinlerin bitmesi ve talebin işverene en az bir ay önce yazılı olarak bildirilmesi gerektiği düzenlenmiştir. Illk olarak isş K. m. 74'te öngörülen izinlerin bitmesinden ne anlaşııması gerektiği açıklığa kavuşturulmalıdır. İ̧̧ K. m. 74'te öngörülen izinlerden anlaşılması gereken analık izni, haftalık çalışma süresinin yarısı kadar ücretsiz izin ve altı aya kadar ücretsiz izindir. Kullandırılması zorunlu olan analık izninin bitiminden itibaren kullanılma sırası iş̧̧i için seçmeli nitelik taşıyan ve kullanılıp kullanılmayacağı da işçinin iradesine bağıı olan haftalık çalışma süresinin yarısı kadar ücretsiz izin ile altı aya kadar ücretsiz izinlerden, kısmi süreli çalışma hakkından yararlanabilmek için biri ya da her ikisinin de tüketilmesi zorunluluğundan söz edilemeyeceği kanaatindeyiz. Yönetmelik m. 8/1'de de kısmi süreli çalışma talebinde bulunulabilmesi için bitmesi öngörülen bu üç iznin "veya" ile bağlanması bu görüşü destekler niteliktedir. Ne var ki analık izninin bitiminden sonra kadın iş̧̧inin kısmi süreli çalışma hakkını kullanmasından evvel haftalık çalışma süresinin yarısı kadar ücretsiz izin hakkını kullanıp aynı zamanda yarım çalışma ödeneğinden yararlanacağı bir düzende çalışmayı tercih etmesi muhtemeldir. Dolayısıyla uygulamada kısmi süreli çalışma hakkının daha çok altı aya kadar ücretsiz izin hakkı ile ikame edilebilir bir niteliğe bürüneceği söylenebilir. Tekrar belirtelim ki kısmi süreli çalışma hakkından yararlanmak, altı aya kadar ücretsiz izin hakkı kullanılmayarak da tercih edilebilir. Hatta Yönetmelik m. 8'de belirtildiği üzere kısmi süreli çalışma talebi, ücretsiz izin süresi kesilerek de yapılabilir. Ücretsiz iznin tamamının kullanılması şartı aranmaz. Analık izni ile haftalık çalışma süresinin yarısı kadar ücretsiz izin bakımından ise bunlar kullanılırken izin süresi dolmadan bu haktan yararlanmak için talepte bulunulması mümkün değildir (Köseoğlu, 2017: 115-116). iş K. m. 74'te öngörülen izinlerin bitmesinden ne anlaşılması gerektiği bu şekilde açıklandıktan sonra kısmi süreli çalışma hakkından faydalanmaya başlamadan en az bir ay önceden işverene yapılması gereken talebin de üzerinde durmak 
gerekir. Zira Yönetmelik m.9'da buna ilişkin ayrıntılı düzenlemeler getirilmiştir. Buna göre, işçinin kısmi süreli çalışma talebinde, kısmi süreli çalışmaya başlayacağı tarih ile tüm iş günlerinde çalışılacak olması hâlinde çalışmanın başlama ve bitiş saatleri, haftanın belirli günlerinde çalışılacak olması hâlinde ise tercih edilen iş günleri yer alır. İşçi, eşinin çalıştığına dair belgeyi kısmi süreli çalışma talebine eklemek zorundadır. İş̧̧inin kısmi süreli çalışma talep dilekçesi, işveren tarafından işçinin özlük dosyasında saklanır. Son olarak kısmi süreli çalışma hakkından yararlanmak üzere talepte bulunan işçinin işverence bu talebinin reddinin mümkün olmadığını da belirtelim. Zira haftalık çalışma süresinin yarısı kadar ücretsiz izin hakkında olduğu gibi burada da kanundan doğan değiştirici yenilik doğuran bir hak söz konusudur (Ekonomi, 2017: 24). Ayrıca bu talebin geçerli fesih nedeni sayılması da mümkün değildir. Yönetmelik m. 11'de usulüne uygun olarak yapılan kısmi süreli çalışma talebinin, bildirim tarihinden itibaren en geç bir ay içinde işveren tarafından karşılanacağı ve işveren tarafından süresi içinde iş̧̧inin talep dilekçesine cevap verilmemesi hâlinde, talebin iş̧̧inin dilekçesinde belirtilen tarihte veya bu tarihi takip eden ilk iş gününde geçerlilik kazanacağı hüküm altına alınmıştır.

Kısmi süreli çalışma hakkından yararlanılabilmesinin bir diğer şartı da işçinin Yönetmelik m. 12'de belirtilen işlerde çalışmıyor olmasıdır. Buna göre özel sağlık kuruluşlarında ilgili mevzuat uyarınca mesul müdür, sorumlu hekim, laboratuvar sorumlusu ve sağık hizmetinden sayılan işlerde tam zamanlı çalışması öngörülenler tarafından yerine getirilen işlerde, nitelikleri dolayısıyla sürekli çalıştıkları için durmaksızın birbiri ardına postalar hâlinde işçi çalıştırılarak yürütülen sanayiden sayılan işlerde, nitelikleri dolayısıyla bir yıldan az süren mevsimlik, kampanya veya taahhüt işlerinde, iş süresinin haftanın çalışma günlerine bölünmesi suretiyle yürütülmesine nitelikleri bakımından uygun olmayan işlerde kısmi süreli çalışma ancak işverenin uygun bulması halinde yapılabilecektir. Yönetmelik $\mathrm{m} .16^{\prime}$ da sağlık hizmetinden sayılan işlerin; tabipler ve tıpta uzmanlık mevzuatına göre uzman olanlar, hemşire, ebe ve optisyenler ile 11.4.1928 tarihli ve 1219 sayılı Tababet ve Şuabatı San'atlarının Tarzı İcrasına Dair Kanunun ek m. 13'de tanımlanan diğer meslek mensupları tarafından yerine getirilen işleri ifade edeceği düzenlenmiştir. Bunun dışında bu haktan yararlanılabilmesi bakımından işyerinin büyüklüğüne, işyerinde çalışan iş̧̧i sayısına herhangi bir önem atfedilmemesi eleştiriye açıktır (Bu eksikliğin özellikle küçük işverenler için büyük yük getireceği ile ilgili açıklamalar için bkz. Caniklioğlu, 2017: 119).

\subsection{Kısmi Süreli Çalışmanın Hükümleri}

Yukarıda talep şartına ilişkin açıklamalarımızda belirttiğimiz üzere, işçinin kısmi süreli çalışma talebinde, kısmi süreli çalışmaya başlayacağı tarih ile tüm iş günlerinde çalışılacak olması hâlinde çalışmanın başlama ve bitiş saatleri, haftanın belirli günlerinde çalışılacak olması hâlinde ise tercih edilen iş günleri yer alacaktır. Ne var ki kısmi süreli çalışma talebini karşılamak zorunda olan işverenin, işçinin talebinde belirttiği iş günleri ya da çalışma saatleri ile de bağlı olduğundan söz etmek mümkün değildir. Yönetmelik m. 15'te kısmi süreli çalışmanın belirlenen günlük ve haftalık çalışma süresi içerisinde yapılacağı zaman aralığı, o yerin gelenekleri, işçinin yapmakta olduğu işin niteliği ve işçinin talebi dikkate alınarak işveren tarafından belirleneceği hüküm altına alınmıştır. Kısmi süreli çalışma düzeninin işveren tarafından belirlenmesinin öngörülmesindense işçinin talebi yönünde belirlenmesi ve bunun denetiminin de dürüstlük kuralı ve sadakat borcu bağlamında yapııması daha isabetli bir çözüm olabilirdi.

Kısmi süreli çalışan işçinin ücret ve paraya ilişkin bölünebilir menfaatleri çalıştığı süreye orantılı olarak ödenir. İş $\mathrm{K} \mathrm{m}$. 13/2'de bu yönde açık bir düzenlenme bulunmakla birlikte, benzer düzenlemeye Yönetmelik m.15/2'de de yer verilmiştir. Bu bağlamda kısmi süreli çalışma hakkını kullanan işçinin haftalık çalışma süresinin yarısı kadar ücretsiz izin hakkında olduğu gibi bir ödenekten yararlanma imkânı bulunmamaktadır. Bundan başka kısmi süreli çalışma hakkından yararlananların sosyal güvenlik bağlamında da sorunlarla karşılaşacağı bellidir. Zira kısmi süreli çalışmaya geçmekle birlikte gerek prim ödeme gün sayıları gerekse de ödenen prim miktarında bir azalma olacaktır (Prim ödeme gün sayısı ve prim miktarındaki azalmanın olası etkilerinden kurtulmak için sigortalı isteğe bağlı sigortalııktan yararlanabilir. Ayrıntılı açıklama için bkz. Güzel, Okur ve Caniklioğlu, 2016: 178). Bu noktada belirtmek isteriz ki çocuğun bakımı ve yetiştirilmesine ilişkin olarak yapılmaya çalışılan mevzuat yenileme ve iyileştirmesinde kısmi süreli iş sözleşmesi kurumundan faydalanılmasının seçilmiş olması yerinde kabul edilebilir. Zira böylece ebeveynlerin ki bu çoğunlukla kadın olacağından kadın işçinin, çalışma yaşamından kopmasının önüne geçilmesi sağlanır. Ancak kısmi süreli iş sözleşmesine uygulanacak kurallar yukarıda açıklanan sonuçların doğması bağlamında bu yenileme ve iyileştirme hareketini en hafif deyimiyle amacına ulaşmaktan uzak, yetersiz kılmaktadır (Fransa'da kısmi süreli çalışma hakkını kullanan ebeveynlere değişen şartlara göre yardım yapıldığı ile ilgili ayrıntılı açıklamalar için bkz. Koç, 2016: 203).

Kısmi süreli çalışmaya başlayan iş̧̧inin tam zamanlı çalışmaya dönebilmesi mümkün olup bu hak kısmi süreli çalışmaya başlama anından sonra herhangi bir asgari sürenin geçmesi şartına da bağlanmamıştır. Dolayısıyla kısmi süreli çalışmaya başlayan işçi her zaman tam zamanlı çalışmaya dönebilirse de işverene bunu en az bir ay önce yazılı olarak bildirmek zorundadır. Ayrıca kısmi süreli çalışmaya başlayan işçi, tam zamanlı çalışmaya döner ise aynı çocuk için bir daha bu haktan faydalanamaz. Burada üzerinde durulması gereken iki husus mevcut olup bunlardan ilki, çocuğun mecburi ilköğretim çağı başlamasına rağmen iş̧̧inin tam zamanlı çalışmaya geçme yönünde bir talepte bulunmamasıdır. Çocuğun mecburi ilköğretim çağının başlamasına kadar işçinin tam zamanlı çalışmaya geçme yönünde bir talepte bulunmaması halinde öğretide bir görüş, mecburi ilköğretim çağının gelmesi ile işverenin işçiden tam süreli çalışmaya geçmesi yönünde talepte bulunabileceğini ve işçinin bu talebe olumlu cevap vermek zorunda olduğu yönündedir (Çelik, Caniklioğlu ve Canbolat, 2016: 156). Kanunun kısmi süreli çalışmaya geçme talebine ilişkin normun amacına aykırı düzenlemesi ile birlikte değerlendirildiğinde söz konusu görüşe katıldığımızı belirtmek isteriz. Aksi yönde bir görüş benimsenmesi halinde ise 
işverenin bu talebinin çalışma koşullarında esaslı değişiklik niteliği taşıyacağından İş K.'nun 22. maddesinin uygulanacağından söz edilebilir. İkinci olarak üzerinde durulması gereken husus ise işçinin tam zamanlı çalışmaya dönme talebinin işverence yerine getirilmemesidir. Bu durumda işçi için derhal fesih hakkı söz konusu olacağı gibi işverenin alacaklı temerrüdünden de söz edilebilir. TBK m. 408'de işverenin temerrüdü düzenlenmekte olup buna göre, işveren, iş görme ediminin yerine getirilmesini kusuruyla engellerse veya edimi kabulde temerrüde düşerse, işçiye ücretini ödemekle yükümlü olup, işçiden bu edimini daha sonra yerine getirmesini isteyemez. Dolayısıyla işveren, iş̧̧inin tam süreli çalışmasını engeller ya da kabul etmez ise işçinin tam süreli çalışmaya dayalı ücretini ödemekle yükümlü olur.

Kısmi süreli çalışma hakkından yararlanmak isteyen işçinin varlığı, işvereni söz konusu iş gücü açığını karşılamak zorunda bırakabilir. Bu durumda işverenin en olağan aksiyonu yeni bir iş̧̧i ile iş sözleşmesi yapmasıdır. Kanun koyucu özellikle kısmi süreli çalışmadan tam zamanlı çalışmaya geçilmesi ile söz konusu iş̧̧inin iş sözleşmesinin akıbetine ilişkin olmak üzere böyle bir durumda, işe alınan işçinin iş sözleşmesi kendiliğinden sona ereceğini düzenlemiştir. Yine Yönetmelik m. 14/4 ile ayrıca kısmi süreli çalışmaya geçen işçinin iş sözleşmesini feshetmesi hâlinde, yerine alınan işçinin iş sözleşmesi yazılı onayı olması koşuluyla fesih tarihinden itibaren belirsiz ve tam süreli sözleşmeye dönüşeceği düzenlenmiştir. Söz konusu düzenlemeler çeşitli sorunlara yol açacak niteliktedir. Öncelikli problem kanun koyucunun kısmi süreli çalışmaya geçen işçinin yerine alınan işçinin iş sözleşmesinin türünü ne olarak belirlemek istediğine ilişkindir. Her iki hükmün lafzı dikkate alındığında kanun koyucunun bu sözleşmeyi objektif sebebin varlığına dayalı bir belirli süreli iş sözleşmesi olarak gördüğü anlaşılmaktadır. Zira "kendiliğinden sona erme" belirli süreli iş sözleşmesinin bir özelliğidir. Yine kısmi süreli çalışmaya geçen işçinin iş sözleşmesini feshetmesi hâlinde yerine alınan işçinin iş sözleşmesinin "belirsiz süreli sözleşme"ye dönüşeceği hükmünün aksi de belirli süreli iş sözleşmesinin varlığını güçlendirmektedir. Öğretide bir görüş, sözleşmenin kendiliğinden sona ereceğine ilişkin hüküm de göz önüne alındığında kanun koyucunun objektif nedene dayalı belirli süreli iş sözleşmesinden hareket ettiğini belirtmektedir (Ekonomi, 2017: 55). Diğer bir görüş de belirli süreli iş sözleşmesi varlığını kabul ederken daha ayrıntılı bir gerekçe sunmaktadır. Yazara göre, Kanunda öngörülen kısmi süreli çalışma hakkını kullanan işçinin yerine alınan iş̧̧i ile yapılan iş sözleşmesi de "belirli bir olgunun ortaya çıkması" objektif koşuluna bağlı olarak yapılan belirli süreli bir iş sözleşmesidir. Gerçekten, işyerinde işletmenin normal faaliyetin veya mutad durumun dışında bir olgu ortaya çıkabilir ve geçici olarak işgücüne intiyaç duyulabilir. Ayrıca tarafların gerçekleşmesi muhakkak ama gerçekleşme tarihi önceden bilinmeyen bir olayı vade olarak göstermeleri halinde de sözleşme belirli süreli iş sözleşmesi olarak kabul edilir. Yine taraflar iş sözleşmesinin sona ermesine ilişkin olarak açıkça bir vade kararlaştırmamış olsalar da, sözleşmenin konusu olan işten de sözleşmenin belirli süreli olduğu sonucu çıkartılabilir. O halde, sözleşmenin belirli süreli iş sözleşmesi olarak kabulü için vadenin varlığı yeterli olup, kesin olması (belirli tarih, gün ay gibi) gerekli değildir (Köseoğlu, 2017: 120). Bir başka görüş ise bir iş sözleşmesinin belirli süreli olduğundan söz edebilmek için o sözleşmenin ne zaman sonra ereceğinin önceden bilinmesi ya da bilinebilir, öngörülebilir olması gerektiğini, kısmi süreli iş sözleşmesine geçen iş̧̧inin ne zaman tam zamanlı sözleşmeye geçeceğinin önceden belli olmadığını, işçinin istediği herhangi bir zamanda tam süreli iş sözleşmesine geçebileceğini belirterek bu sözleşmenin belirli süreli iş sözleşmesi olmadığını açıklamaktadır. Yine aynı görüşe göre, ikame işçinin sözleşmesinin azami süreli iş sözleşmesi niteliği taşıdığı da tartışmaya açıktır. Zira Kanunda kısmi süreli sözleşmeye geçiş talebinin ne zamana kadar yapılabileceği hüküm altına alınmış, ancak kısmi süreli iş sözleşmesinden tam süreli sözleşmeye en geç ne zaman geçilmesi gerektiği ya da kendiliğinden tam süreli sözleşmeye dönüş zamanı konusunda bir hükme yer verilmemiştir. Bu nedenle, taraflarca sözleşmeye özel bir hüküm konulmadığı sürece bu sözleşmenin ne zaman sona ereceği belli değildir. Dolayısıyla ikame iş̧̧i ile yapılan sözleşme belirli süreli sözleşme olarak kabul edilemeyecektir. Eğer kısmi süreli iş sözleşmesine geçen işçinin bu çalışmasının ne zamana kadar devam edeceği açıkça belirlenmiş, işçinin yerine işe alınan işçi ile yapılan sözleşme de buna uygun olarak sürelendirilmişse o zaman ikame işçi ile işveren arasındaki sözleşme azami süreli iş sözleşmesi olarak nitelendirilebilecektir. Dolayısıyla işveren ile ikame işçi arasında açıkça belirli süreli bir iş sözleşmesi yapılmadığı sürece sözleşmenin belirsiz süreli olarak kabul edilmesi gerekir (Caniklioğlu, 2017: 136137). Mevcut düzenleme karşııında söz konusu tartışmanın sona ermesi zor görünse de ikinci görüş kapsamında gerek belirli süreli iş sözleşmesi gerekse de azami süreli iş sözleşmesi bağlamında getirilen eleştirilere katılmaktayız. Ancak yasal düzenlemenin mevcut hali bakımından ikame işçi ile yapılan iş sözleşmesinin bozucu şarta bağlandığı da düşünülebilir (Bozucu şarta bağlı iş sözleşmeleri ile ilgili ayrıntılı açıklamalar için bkz. Alpagut, 1998: 15 vd.; Bozkurt Gümrükçüoğlu, 2012: 33 vd.). Zira söz konusu iş sözleşmesinin sona ermesi kısmi süreli çalışmaya geçen işçinin tam süreli çalışmaya dönmesine bağlanmıs olup mevcut yasal düzenleme bakımından bu durum, gerçekleşip gerçekleșmeyeceği bilinmeyen bir olgu olarak karşımıza çıkmaktadır. Ne var ki bu durumun işletme rizikosu içinde yer almasından ötürü işçiye yüklenemeyeceğinin kabulü ile bozucu şartın geçersiz sayılarak sözleşmeye belirsiz süreli iş sözleşmesi hükümlerinin uygulanmasının daha yerinde olacağı kanaatindeyiz. Böylece belirli süreli iş sözleşmesinin işçi aleyhine olan sonuçları bertaraf edilip işçinin belirsiz süreli iş sözleşmesinin feshe bağı sonuçlarından yararlanması sağlanabilir

\section{SONUÇ}

Hukukumuzda analık hali ile ilgili olmak üzere özellikle kadın işçiyi koruyucu hükümler uzun zamandır mevcuttur. Bu niteliğe sahip düzenlemeler, uluslararası alanda olduğu gibi ulusal hukukta da gelişimini sürdürmektedir. Bu gelişimin son örneği ise 6663 sayılı Kanun ile iş̧ K. ve İşsizlik Sigortası K.'nda yapılan değişikliklerdir. Bu değişiklikler esas itibariyle doğum sonrası haftalık çalışma süresinin yarısı kadar ücretsiz izin hakkı ile kısmi süreli çalışma hakkına ilişkindir. Bu önemli bir gelişmedir, zira özellikle haftalık çalışma süresinin yarısı kadar ücretsiz izin hakkı ile kadın iş̧̧i, altı aya kadar ücretsiz izin hakkını kullanmak zorunda kalmadan ve buna nazaran ücret ile sosyal güvenlik bağlamında kanunun öngördüğü sürelerle kısmen de 
olsa güvenceli bir konuma kavuşmuştur. Yine kısmi süreli çalışma hakkının ebeveynlerden birine yani hem erkek hem de kadın işçiye tanınması hukukumuzun önemli eksikliklerinden olan ebeveyn izinleri bağlamında önemli bir yenilik arz etmektedir. Ne var ki yeni düzenlemeler ayrıntılı olarak incelendiğinde içerisinde pek çok sorunu barındırdığı tespit edilmektedir. Bu sorunlar hali hazırda ya da ilerleyen dönemlerde hakkı etkisizleştirerek kullanılmaz hale getirebilecek niteliktedirler. Dolayısıyla yorum yoluyla ya da yasal değişikliklerle yeni koruyucu düzenlemelerin etkin şekilde uygulanır olması sağlanmalıdır.

\section{KAYNAKLAR}

Alpagut, G., (1998). Belirli Süreli Hizmet Sözleşmesi, İstanbul.

Bozkurt Gümrükçüoğlu, Y., (2012). Türk İş Hukuku’nda Belirli Süreli İş Sözleşmesi, İstanbul.

Caniklioğlu, N., (2017). Kısmi Süreli Çalışmaya Geçiş ve Yarım Çalışma Ödeneği, Emeğin Hukuku Kurultayı-2 (27 Mayıs 2016$)$, Ankara, s. 115151.

Çelik, N., Caniklioğlu, N., Canbolat, T., (2016). İş Hukuku Dersleri, Yenilenmiş 29. Baskı, İstanbul.

Ekonomi, M., (2017). Doğum veya Evlat Edinme Sonrası Çocuğun Bakımı ve Yetiştirilmesi Amacıyla Ücretsiz İzin ve Kısmi Süreli Çalışma Hakları, Legal iSGHD, C. 53, s. 21-58.

Güzel, A., Okur, A.R., Caniklioğlu, N., (2016). Sosyal Güvenlik Hukuku, İstanbul.

Koç, S., (2016). İş Hukukunda Ebeveyn İzinleri, İş Hukukunda Genç Yaklaşımlar II, İstanbul, s. 195-209.

Köseoğlu, A. C., (2016). Türk İş Hukukunda Analık, İş ve Hayat Dergisi, 2017/4, s. 97-124.

Mollamahmutoğlu, H., Astarlı, M., Baysal, U., (2014). İş Hukuku, Gözden Geçirilmiş ve Genişletilmiş 6. Bası, Ankara.

Sözer, A.N., (2015). Türk Sosyal Sigortalar Hukuku, 2. Baskı, İstanbul.

Süzek, S., (2016). İş Hukuku, Yenilenmiş 12. Baskı, İstanbul.

Ulusoy, T., (2017). Bir Sosyal Koruma Olarak İş Kanunu'nda Gebe ve Yeni Doğum Yapan Kadın Çalışanlara Yönelik İzinler ve Kısmi Süreli Çalışma Hakkı Üzerine Güncel Gelişmelerin Değerlendirilmesi, Çalışma ve Toplum Dergisi, 2017/2, s. 741-766. 